\title{
O Dialogismo e a Paleontologia da Linguagem: o Círculo de Bakhtin na episteme soviética (1920-1930)
}

\author{
Serguei Tchougounnikov * \\ Colégio Internacional do Sul de Estocolmo
}

\begin{abstract}
This article analyzes conceptions of Bakhtin's Circle during the government of Joseph Vissioronovich Djougachvilli, Marshal Stalin, in the Russian/Soviet context. The present approach will explore the relationship between Bakhtin/Volochinov's sociological method, proposed in Marxism and Philosophy of Language, and the conceptions on language proposed by N. Yakovlevitch Marr (The New Doctrine) to support some principles that could maintain a National Unified State during Stalin's political regime.

Key-words: ideological sign, ideology, social body, material body, nationalism, evolution and hibridity (mixing) of languages
\end{abstract}

Foi em junho de 1950 que Joseph Vissorionovitch Djougachvilli, o Marechal Stalin, fez um pronunciamento, pela primeira vez, sobre questões de Lingüística Geral. Um longo artigo "O Marxismo e os Problemas da Lingüística", publicado sob a forma de brochura aparece no jornal Pravda. O texto de Stalin contém uma severa crítica à "Nova Teoria da Linguagem" de Nicolai Marr. Durante os trinta anos precedentes, desde o final dos anos 20, esta teoria tinha sido, entretanto, na União Soviética, a doutrina lingüística oficial.

Nicolai Jakovlevicht Marr(1865-1934), arqueólogo e lingüista, poliglota e especialista em línguas e civilizações caucasianas, internacionalmente reconhecido, tornou-se um acadêmico antes da revolução de outubro de 1912. Dentro do regime soviético, ele foi coberto de todas as honras acadêmicas e posto no comando de uma instituição de pesquisa, criada para ele. Mas sua glória escandalosa se deveu à sua teoria sobre a linguagem. A Lingüística marrista considera a gênese da linguagem em função das atividades produtivas e as relaciona diretamente com a evolução da sociedade. Tudo sendo parte das superestruturas e sendo um produto das formações sócio-históricas de classe, a linguagem teria feito verdadeiros "saltos revolucionários" análogos à passagem de uma formação sócio-econômica para outra, sob a pressão de forças produtivas que remetem, em seu progresso, ao quadro de uma forma de produção antiga.

\footnotetext{
${ }^{*}$ Conferência proferida pelo Prof. Tchougounnikov em 5.12.2003 no Instituto de Letras da Universidade Federal do Rio Grande do Sul.
} 
O marrismo sustentou, assim, a idéia de comunidade de línguas de uma mesma classe, à revelia das, "fronteiras genéticas" das línguas nacionais. Foi preciso, portanto, uma forma de "sobredeterminação universal" que correspondesse a um outro elemento do marrismo: seu espírito monogenético. E isso apareceu na tese dos quatro elementos fonéticos universais, concebidos como material de um único processo glotológico, onde o cruzamento se encontra na origem de todas as línguas.

De acordo com Marr, os estágios sucessivos no processo do pensamento humano são três sistemas para a construção da palavra oral, do discurso, oriundos, na totalidade, dos diversos sistemas econômicos e das estruturas sociais que lhe correspondem. São eles: a) comunismo primitivo, dotado da estrutura sintática, com o poli-semantismo das palavras, sem distinção entre as significações básicas e funcionais; b) estrutura social baseada na separação de diversos aspectos da economia e da divisão do trabalho; isto é, configurada pela divisão pela divisão da sociedade em ocupações diferentes.; c) estratificação da própria sociedade em grupos produtivos e técnicos, os quais representam as formas primitivas de agrupamentos.

Esta organização social é acompanhada pela estrutura linguageira que distingue as partes do discurso, diversas proposições na frase, diversas partes nas proposições,etc... As partes do discurso, assim distintas, são dotadas de diversas palavras funcionais que são transformadas, mais tarde, em elementos morfológicos com a diferenciação, nas palavras, entre as significações de base e as significações funcionais desenvolvidas a partir das significações de base: a sociedade estática ou de classe, dotada de divisão técnica do trabalho, a qual é caracterizada pela morfologia de ordem flexional.

Os estágios do pensamento ${ }^{1}$ correspondem, de acordo com Marr, a estágios morfológicos. Outro nome da nova lingüística de Marr é jafetologia. Marr explica que, enquanto outros nomes bíblicos, como Sim e Kham foram tomados de outras línguas(grupos semíticos e camíticos de línguas), ele adota o nome do terceiro filho de Noé, Jafé, para designar a totalidade de línguas faladas na região caucasiana.

Um grupo de "jovens camaradas" julgou poder colocar três questões sobre alguns problemas de lingüística, para as quais, de modo essencial, o texto de Stalin traz as seguintes respostas:

a) a língua não é uma superestrutura sobre a base material(econômica) da sociedade;

b) a língua de classe não existe, é a língua geral de todo povo(obshenarodnyj jazik) que realmente existe. A existência de dialetos e jargões não contradiz, mas confirma a existência de uma língua geral do povo, a partir da qual os dialetos e jargões são ramificações, estando a ela subordinados;

c) a lingüística de Marr, com suas teses confusas sobre a existência de línguas de classe e sua definição de língua como superestrutura revelou-se nociva; torna-se necessário por fim à dominância do marrismo na lingüística soviética. E isto pode-se fazer dentro do quadro de uma discussão científica livre. ${ }^{2}$

\footnotetext{
${ }^{1}$ L. Thomas. As Teorias lingüísticas de Nicolai Marr. Berkeley,1975,p.125-6.
}

${ }^{2}$ J. Stalin. Marxismo e problemas de lingüística. Stanford University, 1967. 
Entre as conseqüências produzidas pelo texto de Stalin, Vladimir Alpatov menciona: 1) a reabilitação da Lingüística russa diante da revolução de Outubro; 2) a reabilitação do método histórico-comparativo; 3) a aceitação da teoria de parentesco de línguas: a teoria de uma proto-língua não foi admitida por Stalin, mas o parentesco entre as línguas sim. É o caso das línguas eslavas, por exemplo, que deixou fora de dúvida, o que liberou o comparatismo em Lingüística de acusações de racismo e de imperialismo. ${ }^{3}$

\section{O Círculo de Bakhtin No Contexto Soviético}

Os escritos teóricos de Mikhail Bakhtin e do Círculo de Bakhtin(Bakhtin, Medvedev, Volochinov) são habitualmente considerados como uma ilha de resistência à realidade totalitária do stalinismo. Diversos estudos(Boris Grois, M. Keith Booker e D. Duraga) têm valorizado certas relações entre os conceitos do Círculo de Bakhtin e a realidade soviética no período de Stalin. Esses autores buscaram mostrar a existência de laços ou de trocas recíprocas entre o conjunto conceitual e a atmosfera intelectual da União Soviética da época. Pode-sequestionar:"Bakhtin era um stalinista?"ou ainda"O carnaval de Bakhtin é uma realidade cotidiana da URSS dos anos 30?" Pode-se experimentar dispensar problemáticas comuns nos textos do Círculo de Bakhtin e no texto de Stalin sobre problemas de lingüística geral. Tais temas comuns não são simples coincidências textuais ou traços de filiações diretas de pensamento, mas refletem os verdadeiros problemas sócio-lingüísticos e formulam métodos próprios para resolvê-los. A própria formulação dos problemas, totalmente apartada do quadro epistemológico destes textos, em relação às Ciências Sociais deste período, não possui nada de inexplicável. Propomos, portanto, uma leitura comparada de certas formulações do texto de Stalin e dos textos do Círculo de Bakhtin, buscando liberar do projeto dialógico deste último o"substrato jafético" em proveito da nova lingüística de Marr.

As noções de“ideológico” e de signo ideológico são interpretadas por Volochinov, aliás Bakhtin, na introdução de "Marxismo e Filosofia da Linguagem.(Problemas fundamentais de um método sociológico aplicado à ciência da linguagem, 1929). (Marksizm i filosofia jazika, Osnovnyje problemy sociologicëskogo metoda v nauke o jazyke). O signo ideológico é definido em função do potencial de refração de todo fenômeno ideológico ou social. É a maneira de refratar ou de transpor a realidade objetiva própria à consciência humana. A noção de signo ideológico exprime a tese do Círculo de Bakhtin sobre o caráter necessariamente material de todo fenômeno deste tipo. A afirmação que abre o livro de Volochinov propõe que tudo que é ideológico é expresso por um material semiótico e, inversamente, tudo que é expresso ou capaz de ser expresso, possui um valor ideológico. Os utensílios e os objetos materiais estão dispostos entre os fenômenos ideológicos( como palavra, texto, discurso) de acordo com o critério de sua realização material. O signo ideológico encontra uma manifestação natural na entoação como expressão de valor ou de atitude ideológica. Ele realiza o que Volochinov designa "a percepção pelo"nós"(myperezivanie), diferentemente da percepção por "moi”(já-perezivanie), isto é, ele

\footnotetext{
${ }^{3}$ V. Alpatov. Istorija linvisticeskikh ucenij, Moscou, 1998, p.186-
} 
exprime o vivido coletivo por oposição ao vivido individual, O Freudismo, Leningrado, 1927(Frejdizm).Deste modo, nenhuma percepção monológica, pessoal ou não-dialógica é possível, uma vez que a consciência humana está constituída de valores sociais, ideológicos ou coletivos.

P. Medvedev, em sua crítica sobre a metodologia formalista, "O método formal em ciência da Literatura: introdução crítica a uma poética sociológica",1928 (Formal " nyj metod $v$ literaturovedenii kritičëskoje vvedenije $v$ sociologičeskuju poetiku) introduziu os termos ideologema e avaliação social. O ideologema é definido como uma zona onde a distinção entre a psicologia e o social se encontra abolida; é o meio ideológico ou social materializado nas formas de tipo artístico ou a junção do meio ideológico(social) e das formas artísticas que ele condiciona e dentro das quais é refletido. Há,de acordo com Medvedev, aliás Bakhtin, uma outra noção importante, do ponto de vista "ideológico", que significa o encontro dialógico por intermédio do discurso: a ponte ideológica, isto é, aquele que fala projeta entre ele próprio e o outro, aquilo de que fala. O encontro entre "moi" e o outro não se faz possível sem esta ponte.

No que concerne ao"ideológico", ao dialógico ou polifônico, pode-se apreender de Bakhtin, Volchinov e Medvedev que: 1) é uma dimensão fundamental da linguagem humana; 2) é um elemento incorpóreo contido em todo enunciado; 3) é a própria condição do funcionamento lingüístico e da constituição do social. A Lingüística formal ou abstrata, no mundo ocidental, não acessou a esta realidade fundamental da linguagem e isto porque ela deforma seu objeto. Somente a poética sociológica, o método sociológico"que ainda não existe", acrescenta Medvedev aliás Bakhtin, nos anos 20, pode abordá-lo e explicá-lo.

Todos esses conceitos têm em comum as seguintes implicações:

\section{O indivíduo está constantemente investido pelo meio social ambientado por intermédio dos signos lingüísticos.}

"As normas lingüísticas, a sistemática da língua são análogas às normas morais, jurídicas, estéticas no sentido de que estas normas não existem senão em função da consciência dos indivíduos que compartilham uma sociedade governada por elas. A língua não é um fenômeno inteiramente objetivo(como as leis fisicas), nem inteiramente subjetivo(como as impressões digitais). A liberdade individual, na linguagem, depende sempre da razão constantemente cambiável entre a palavra interior( que é para ele um pensamento sempre consciente) e a palavra exterior. A sociedade investe constantemente o indivíduo por intermédio de signos e da linguagem.",

\section{O meio é um dispositivo produtor de signos}

Para Bakhtin, aliás Medvedev, todo produto ideológico se exprime no material ideológico objetivamente disponível: “ na palavra, no som, no gesto, na combinação

\footnotetext{
${ }^{4}$ K. Clark \& M. Holquist, Mikhail Bakhtine, Cambridge/London, 1984, p.224.
} 
de massas, de linhas, de cores, de corpos vivos, etc.." 5 Todos os produtos da criação ideológica são coisas materiais. São coisas de tipo particular que contêm significações, sentidos, valores internos. Mas é somente por sua realização ou pelo seu acabamento que eles tornam a realidade ideológica. Elas chegam à realidade, por suas realizações, em um material semiótico preciso.( $v$ opredelennom znakovom materiale) Por meio deste material semiótico, elas tornam-se uma parte da realidade que circunda $o$ homem $^{6}$. De acordo com Volochinov, a Psicologia Social se manifesta como uma transição entre a ordem sócio-política e a ideologia propriamente dita, ela se dá materialmente como interação verbal. De modo distinto do fenômeno do Nacionalismo, definido por Volochinov como um termo metafísico ou mítico, a Psicologia social é ativa, não no interior do psiquismo, mas inteiramente fora, na palavra, no gesto, na ação. ${ }^{7}$

A Psicologia social é definida como o conjunto de manifestações discursivas, nas quais se banham todas as formas e tipos de criação ideológica estáveis ${ }^{8}$. É no seio desta Psicologia social que mudanças apenas perceptíveis a partir da situação social se produzem. Tais mudanças se acumulam e se depositam para formar finalmente" os produtos ideológicos acabados"," Todo signo ideológico externo banha os signos internos que constituem a consciência. Todo signo ideológico exterior nasce deste "mar de signos internos", e continua a viver, pois a "vida do signo" exterior consiste do processo de sua compreensão, de sua vivência, de sua assimilação, isto é, de sua integração renovada no contexto interior. ${ }^{10}$

A materialização, sinônima, aqui, da socialização, definida como condição de todo fenômeno significante ou semiótico, vem a abolir a divisão entre o interno e o externo. O interno, nesta ótica sócio-dialógica, é uma projeção daquilo que é externo à consciência individual das relações discursivas realmente formadas e presentes no espaço inter-social, isto é, vai além da consciência pessoal. Esta última faz parte do espaço sócio-discursivo exterior. Participa do diálogo ou do "polilogos" generalizado, dentro do qual ela não é senão uma parcela delegada e orgânica, ela não possui mais inconsciente, nem de dimensão interna.

\section{O lugar do outro na atividade discursiva individual é constitutivo para o indivíduo que fala.}

É fato que para Volochinov, aliás Bakhtin, a linguagem se define somente por seu potencial comunicacional( ela é sempre translingüística, dialógica) pela estrutura do auditório, pelo outro, e sempre investida do discurso endereçado. Não há discurso sem o outro: o outro real ou virtual é a própria condição de possibilidade do discurso. Trata-se de um fenômeno de engendramento discursivo: o outro é sempre produzido. A palavra e o signo são sempre, por definição, unidades partilhadas. O signo não surge ente dois membros quaisquer da espécie humana: o essencial é que eles sejam

\footnotetext{
${ }^{5}$ M. Bakhtine. Tetraloguija, Moscou, 1998, p.115.

${ }^{6}$ Bakhtine, ibid, p.114.

${ }^{7}$ Bakhtine, ibid, p.312.

${ }^{8}$ Bakhtine, ibid, p.313.

${ }^{9}$ Bakhtine, ibid, p.313.

${ }^{10}$ Bakhtine, ibid, p.328.
} 
organizados socialmente, que componham um grupo ( uma unidade social).É somente assim que o intermediário, a "ponte de signos" pode ter lugar e adquirir forma entre eles.

\section{A produção do outro se faz por meios discursivos, ela é sempre uma produção de si.}

A palavra dialógica, portanto a palavra inserida no enunciado ou no discurso, é sempre uma palavra endereçada a um destinatário. A palavra dialógica é um ato em dois aspectos. A palavra dita interior e o pensamento têm sempre seu auditório social estável: este último compreende o meio, os valores, os motivos, as razões de ser de diversos grupos sociais. Cada palavra emitida exprime o locutor em sua relação com o destinatário. É aqui que surge a instância do ponto de vista. Aquele que fala se dá uma forma verbal do ponto de vista do outro, e, em última instância, do ponto de vista da comunidade da qual faz parte. A palavra é um ponto projetado entre ela mesma e o outro, um território partilhado.

\section{O outro se dá como função do meio ideológico}

O termo ideologia significa para Volochinov, aliás Bakhtin," este universo de signos" que existe simultaneamente na psique e no mundo.É uma realidade intermediária, encarnada, ideológica. É ideológico tudo que coincide com o signo. Tudo que se materializa por intermédio do signo possui um valor ideológico. Ou ainda: esses dois domínios - do ideológico e dos signos coincidem.

A tese, na qual tudo que é ideológico possui um valor semiótico, significa, de acordo com Katherina Clark e Michel Holquist, que todos os produtos do espírito humanodesde os utensílos mais simples até as cosmologias mais complexas - podem executar tarefas por intermédio de signos. ${ }^{11}$ Eles são todos engendrados pelo pensamento(definido por Volochinov, aliás Bakhtin em Freudismo(1927) como uma "palavra interior" ou como consciência não-oficial. A translingüística (termo proposto por Volochinov, aliás Bakhtin, para designar a ciência hipotética das ideologias e dos signos ideológicos nos enunciados) se ocupa do espaço ideológico que é o espaço dos enunciados, de tudo que extrapola as fronteiras de uma palavra. Encontramos na obra de Volochinov, aliás Bakhtin, expressões como"logosfera" como "ecossistema de palavras" $" 12$.

Esse espaço ideológico de palavras, de fenômenos verbais é estratificado, pois as palavras não são sempre idênticas a si mesmas. As mesmas palavras significam coisas diferentes em situações diferentes. A ideologia, sendo para Bakhtin,aliás Volochinov, o universo dos signos, ora no psiquismo, ora no mundo, designa "o social" o mar ou o oceano de relações interpessoais. O signo funciona não somente no espírito individual, mas em uma rede mais vasta de relações interpessoais, no social. Eis a condição de funcionamento do signo. É o mar de signos ou do social que faz com que o signo

\footnotetext{
${ }^{11}$ Clark e Holquist, ibid, p.255.
}

${ }^{12}$ Clark e Holquist, ibid, p.227. 
signifique. O social ou ideológico é, para a consciência humana, o que o mar é para os peixes: meio de habitação, ambiente vital.

\section{O signo ideológico é um fenômeno material}

De acordo com Medvedev, o primeiro princípio da ciência marxista das ideologias é o princípio da encarnação material. Toda criatividade ideológica é inteiramente material, ela se dá sob uma forma inteiramente objetiva. Todo fenômeno ideológico ou social se encontra no mundo objetivo exterior. É a presença ou a realização material da palavra que a torna ideológica ou social. ${ }^{13} \mathrm{O}$ signo ideológico e a palavra (slovo) são para Volochinov, aliás Bakhtin, um corpo, uma unidade quase somática, uma materialização da ideologia. Para explicar a palavra como um fenômeno ideológico, esses autores dão ênfase ao aspecto sensível do signo. Cada fenômeno que funciona como um signo possui uma realização material: no som, na massa física, nas cores, nos movimentos corporais, na entonação. Neste sentido, a realidade do signo é, para ele, inteiramente objetiva. Para o próprio Bakhtin, a compreensão não pode se realizar fora de um tipo de material semiótico, por exemplo, a "palavra interior". A própria consciência se torna um fato valioso somente em sua realização material pelo signo. $\mathrm{O}$ trato dominante da consciência é o de ser representação. Ela não contém senão representações. Cada elemento da consciência representa qualquer coisa, porta uma função simbólica. ${ }^{14}$ É na linguagem que o valor semiótico do signo se realiza.

Em sua crítica ao Freudismo, Volochinov, aliás Bakhtin,(Frejdizm,1927) propõe substituir a dicotomia freudiana inconsciente/consciente por uma outra: palavra interna/palavra externa. A oposição freudiana é considerada como uma falsa oposição, pois nenhuma realidade corresponde ao que Freud designa como "inconsciente". De fato, o inconsciente é uma consciência mascarada, e ele se agita na prática psicanalítica do conflito entre a consciência oficial e a consciência não-oficial. De acordo com Volochinov, aliás Bakhtine, o indivíduo que fala, escolhe em função do meio exterior aquilo que ele manifesta no seu discurso na condição de consciência oficial. A palavra interior que precede a manifestação ou a palavra exterior é sempre consciente. A contradição da teoria psicanalítica é formulada da seguinte maneira: Freud trabalha sobre a linguagem e pretende encontrar o recalque. E, todavia, por definição, a totalidade da linguagem é perfeitamente e inteiramente consciente. $\mathrm{Na}$ linguagem, que é a própria condensação social, não há verdadeira distinção entre o que é externo e interno, é sempre uma questão de estratégia ou de política.

\section{No organismo vivo se encontra necessariamente um centro espiritual, instância de controle e de coordenação do conjunto suas funções, dito "arquitetônico".}

De acordo com Bakhtin, o conceito de arquitetônico, do mesmo modo que o termo chronotopos, fundamental para sua teoria do romance, são derivados de um domínio que possui uma forte tradição no campo russo: a reflexologia do organismo e a

\footnotetext{
${ }^{13}$ Bakhtine, Tetraloguija, p.115.

${ }^{14}$ Clark \& Holquist, ibid, p.225-6.
} 
fisiologia do cérebro. Nas conceitualizações do fisiologista russo Alexandre Ukhtomsky, diretor de um laboratório experimental de Leningrado, onde Bakhtin participava das conferências em 1925, o termo chronotopos designa a função do córtex que relaciona e torna inteligíveis os sinais provenientes dos órgãos de percepção. O conceito de Ukhtomsky fazia parte de sua teoria sobre a atividade nervosa integrada ao corpo por intermédio do "sistema de sistemas" cortical, definido como dominante ${ }^{15}$.

Esta totalidade orgânica do ser vivo se torna, de acordo com Bakhtin, homóloga à totalidade arquitetônica da obra artística, cuja definição remete às teorias estéticas do idealismo e do romantismo alemão( Goethe, Kant, Schelling, e F. Von Schlegel) e a linguagem humana, é, por si mesma, o modelo do universo espiritual de um povo, o espelho de seu espírito nacional. Prosseguindo, buscaremos precisar algumas noções fundamentais para a compreensão das concepções do Círculo de Bakhtin, não mencionadas senão rapidamente na seqüência precedente.

\section{O signo ideológico é um intermediário ideal na condição de veicular o vivido sobredeterminado sem ser determinado ou esgotado pelo material semiótico; ele é um devir e não corresponde jamais inteiramente a este material.}

De fato, o signo ideológico(praticamente identificado à palavra) é definido por Volochinov, aliás Bakhtin, como"um ser efetivo" (dejsvitelnoje bytie). Conseqüência do contato imediato com a base material, este signo refratado transforma ou refrata $o$ ser em devir (stanovjašeesja bytie). ${ }^{16} \mathrm{O}$ signo ideológico, de acordo com Volochinov, contrai e conserva a impulsão de partida que lhe forneceu a base material. A refração exercida por ele é uma conseqüência do fato de que o signo refratado pela base material transmite esta contração ou esta deformação inicial. A partir desta impulsão de partida o signo ideológico contrai a ótica ou o quadro de refração para este "ser em devir". O quadro perceptivo contraído pelo signo guarda esta impulsão inicial transmitida pela base. Em outros termos, a matriz ideológica ofertada pelo signo guarda a memória deste primeiro impacto da base material( a grosso modo, da realidade) sobre o material do signo ou sobre o signo lingüístico neutro. Este contato transforma o signo lingüístico neutro em signo ideológico. $O$ signo ideológico, à diferença do signo algébrico da lingüística formal ou abstrata, define-se por este trato mnêmico que o coloca no contexto ou nas condições de seu emprego. É um termo carregado de memória, ele não é funcional, de tal modo que isto explica a aparição ulterior, de acordo com Volochinov e Bakhtin, da problemática da "memória dos gêneros" e dos "gêneros de palavra" visando a dar conta das condições históricas de produção dos enunciados.

A palavra, na qualidade de signo ideológico, é o próprio meio onde se realizam as acumulações quantitativas das mudanças"que não teve tempo ainda de passar a uma nova qualidade ideológica","que não engendrou uma nova forma ideológica

\footnotetext{
${ }^{15}$ Clark \& Holquist, ibid, p.174.

${ }^{16}$ Bakhtine, Tetraloguija, p.312.
} 
acabada. ${ }^{17}$ A palavra chega a engendrar uma nova forma ideológica acabada por este depósito ou por esta cristalização de transformações sociais. É o equivalente a um organismo que passa bruscamente a um novo estado qualitativo pela acumulação paciente de tratos hereditários transmissíveis pela posteridade. A palavra é sempre externa. É uma realidade exterior: é nesta condição que ela é material. A palavra, na qualidade de signo ideológico, é uma exterioridade integral do fato de que ela não contém nada de exterior. Ela contém seu potencial ideológico em seu material. A base material social( relações de produção) determina todas as formas de interação verbal dos homens. E tais formas, por sua vez, determinam os temas das manifestações discursivas. ${ }^{18}$

\section{A <ótica de classe $>$ na metalinguagem de Medvedev e Volochinov.}

Parece que, da perspectiva genética, o discurso sobre a "língua de classe" se funda sob a percepção do conflito social, mais do que sobre os conflitos raciais. Esta maneira de considerar o antagonismo político como uma luta entre raça superior e inferior reportase ao "grande tratado" evolucionista e biológico que estava em circulação à época.

Walter Benjamin, em seu ensaio sobre Baudelaire, escrito no final dos anos 30 e publicado no final dos anos 50, detém-se sobre esta articulação discursiva entre o social e o racial. Benjamin se reporta, em particular, à obra de Granier de Cassagnac, "História das classes operárias e das classes burguesas (1838), onde ele resume seu conteúdo como segue:'Esta obra esteve no compasso de revelar a origem dos proletários; eles formam uma classe de sub-homens oriundos do cruzamento de bandidos e prostitutas". Benjamin observa que o próprio Marx não evitou esta visão "racial" do conflito de classes. No primeiro livro de "O Capital" vê-se aparecer uma raça singular de "mercadores" (citada por Benjamin) que designa, de acordo com Marx, o proletário. É a partir deste paradigma sócio-biológico que W. Benjamin lê a famosa litania de Baudelaire "Abel e Caim", onde é questionado o combate entre a "raça de Abel" e a "raça de Caim" apresentadas como um conflito de raças pela eternidade. ${ }^{19}$ Benjamin escreve: "Caim, o ancestral dos deserdados aparece aqui como o pai de uma raça que não pode ser outra, senão a raça proletária[...]. É a raça dos que não possuem outra mercadoria, senão a sua própria força de trabalho 20 ". W. Benjamin reata a romantização naturalizada da mais valia a um gênero literário preciso que se desenvolve na Europa no início dos anos 1840, o gênero da "fisiologia". Os autores de fisiologias consagram-se com a descrição de tipos humanos e com a fisiologia das cidades, povos e animais.

È, pois, aqui, o lugar para lembrar uma abertura de Balzac à "Comédia Humana" que coloca diretamente este empreendimento "anatômico" dos "estudos dos costumes" no debate biológico da época, em particular, a idéia da "unidade de composição": " $A$ idéia vinda de uma comparação entre a humanidade e a animalidade.Seria um erro

\footnotetext{
${ }^{17}$ Bakhtine, Tetraloguija, p.312.

${ }^{18}$ Bakhtine, Tetraloguija, p.312-13.

${ }^{19}$ W. Benjamin.”Charles Baudelaire. Um poeta lírico ao apogeu do capitalismo. Paris, 1982,p.37.

${ }^{20}$ Benjamin, ibid,p.37.
} 
crer que a grande querela que, nos últimos tempos, se estabeleceu entre Cuvier e Geoffroy Saint-Hilaire, repousou sobre uma inovação científica. A unidade de composição já ocupava, em outros termos, os maiores espíritos dos dois séculos precedentes. Ao observar as obras extraordinárias dos escritores místicos que se ocuparam das ciências, nas suas relações com o infinito, tais como Swedenborg, Saint Martin, etc., e os escritos dos melhores gênios da História Natural, tais como Leibnitz, Buffon, Charles Bonnet, etc., encontramos nas monadas de Leibniz, nas moléculas orgânicas de Buffon, na força vegetativa de Needham, no encaixe das partes similares de Charles Bonnet, bastante ousado por sua escrita em 1760: "O animal vegeta como a planta"; encontramos [...] os rudimentos da bela lei do ser por ser, sobre a qual repousa a unidade de composição. Não há senão um animal.O criador não se serviu senão de um único e mesmo "patrão" para todos os seres organizados. O animal é um princípio que toma sua forma exterior ou[...] as diferenças de sua forma, no meio onde ele é compelido a se desenvolver. As espécies zoológicas resultam destas diferenças. A proclamação e sustentação deste sistema[...] será a eterna honra de Geoffroy Saint-Hilaire.Ao penetrar este sistema bem antes dos debates, aos quais ele deu lugar, vi que, a partir desta relação, a Sociedade assemelhava-se à Natureza. A Sociedade não fez o homem, criado dos meios onde sua ação se desdobra, sendo os homens diferentes das variações zoológicas? As diferenças entre um soldado, um trabalhador, um administrador, um advogado, um ocioso, um sábio, um homem de Estado, um comerciante, um marinheiro, um poeta, um pobre, um preto, embora mais dificeis de apreender,são também consideráveis àquelas que distinguem o lobo, o leão, o asno, o corvo o tubarão, o lobo marinho, a ovelha, etc. Existiram e existirão, portanto, em todos os tempos ,as Espécies Sociais como existem as Espécies Zoológicas. Se Buffon fez uma magnífica abertura,ensaiando representar em um livre o conjunto da zoologia, não teria ele uma obra desse gênero para fazer à Sociedade? "21

Existe provavelmente uma fonte ainda mais arcaica que influenciou a gênese da noção de "língua de classe", fonte ligada à pré-história semântica do termo "proletário". Esta é empregada, no latim, como proletarius e designava o cidadão pertencente à última classe da sociedade romana. A palavra significa propriamente "aquele que não é considerado útil senão pelos filhos que faz" Santo Agostinho comenta o termo como segue: "seriam proletários aqueles que se ocupariam de colocar crianças no mundo". O termo proletarius é oriundo de proles, nome coletivo do conjunto de crianças, da raça, da estirpe. Este núcleo semântico antigo pôde influenciar a nova definição do termo após a metade do séc. XVIII até 1848 , onde o Manifesto do partido comunista de Marx e de Engels introduziu o termo com sua significação atual. $^{22}$

Marr tinha introduzido bem antes da Revolução de Outubro a idéia que continha o embrião da tese do caráter de classe das línguas.Os analistas de Marr relacionam esta afirmação à sua experiência pessoal, por ocasião de sua estada na Armênia em 1892 . Narra-se que, no curso desta viagem, Marr, que não sabia bem ainda o armênio,

\footnotetext{
${ }^{21}$ H. de Balzac. A comédia humana.Paris, 1976,p.7-8.

${ }^{22}$ Robert. Dicionário histórico da língua francesa.Paris, 1973.
} 
conseguiu compreender os camponeses armênios graças a seu conhecimento do georgiano, ao passo que os sábios monges armênios que o acompanhavam não compreendiam seus compatriotas camponeses. Esta semelhança entre certos dialetos armênios com os georgianos instigou Marr e lhe deu, contra os fatos lingüísticos observáveis, a idéia de parentesco entre as línguas armênia e georgiana. Marr não encontrou termos comuns entre o armênio e o georgiano, senão nos dialetos armênios (parecia tratar-se de empregos tardios) e tampouco nos documentos armênios escritos. Ele tiraria a noção de distinção primordial entre duas línguas apoiando-se em suas noções de ideologema, "da palavra aos acentos" à "avaliação social", dado o mecanismo desta dialética entre a ruptura e a continuidade. De acordo com Volochinov, a palavra é neutra na qualidade de signo lingüístico, mas não é jamais neutra na qualidade de signo ideológico. A palavra-signo lingüístico adquire o estatuto de signo ideológico por interação com o meio social, em função do meio. Este fator exterior( que está entre os homens, enquanto agentes sociais, mas fora deles) transmuta a palavra-signo lingüístico abstrato em signo ideológico engajado pelo deslocamento do acento. Em um espaço socialmente homogêneo, é preciso possuir o mesmo fundo semiótico para obter a mudança dos signos. Esta homogeneidade da mudança, e, por conseqüência, o sucesso da comunicação, é assegurada pela identidade dos acentos ou das avaliações sociais que sobredeterminam os signos lingüísticos abstratos.

A sobredeterminação, em questão, se realiza no nível da palavra interior. $O$ pensamento e a linguagem, sendo uma única e mesma coisa, é a palavra interior que contém a realização possível de todo ato de fala. $\mathrm{O}$ coletivo ou o grupo social está sobredeterminado desde o interior, pelo dispositivo do signo interior. Neste contexto, o problema da língua, na condição de intermediária, não se coloca mais. A consciência não-oficial, que se realiza na palavra interior, torna-se um meio de auto-controle eficaz de toda consciência oficial ou de toda palavra exteriorizada. A tarefa fundamental é, portanto, de produzir uma transmutação ideologicamente necessária na consciência e no nível da palavra interior. Isto se pode fazer pelo intermediário do "reflexo", que consiste da tomada de consciência em vista de uma forma, a escolha de uma única forma de refração do universo.

$\mathrm{Na}$ Europa dos anos 1960-70, tais formulações foram percebidas como uma espécie de revelação e como uma fonte de inspiração conceitual ${ }^{24}$, uma vez que elas se inscrevem no clima espiritual soviético da segunda metade dos anos 20 , sendo consubstanciais para este. Uma fórmula clássica que os marristas fazem aparecer no Programa para as

\footnotetext{
${ }^{24}$ Em seu artigo sobre a obra de Bakhtin (1973), o qual concebeu como poética arruinada, J. Kristeva comenta o aporte conceitual do Círculo de Bakhtin, e coloca diante da questão do caráter ideológico da polifonia para responder pela negativa. De acordo com ela, a polifonia romanesca fez entender diversas ideologias sem desenvolver uma ideologia que lhe seja própria. $\mathrm{O}$ texto não é ideológico, à exceção do texto monológico fundado sobre a unidade do " (moi) falante", que garante a validade de uma ideologia. Em um texto polifônico, a ideologia ou as ideologias são contraditórias,mas elas não são organizadas em vista de um valor qualquer, elas não são pensadas ou julgadas. Elas não funcionam senão como o material ao qual é preciso dar a forma. É neste sentido que o texto polifônico não possui senão uma única ideologia: ideologia formativa, portadora da forma. O texto polifônico não possui ideologia que lhe seja própria. É um dispositivo para expor e esgotar as ideologias em sua confrontação. (J. Kristeva, "A ruína de uma poética" em Formalismo russo,1973:p.113).
} 
escolas secundárias soviéticas em 1932 contém a definição seguinte:“A proposição é uma unidade de comunicação que reflete a realidade refratada pela consciência de classe daquele que fala." ${ }^{, 25}$ Stalin, cuja meta, em 1950, é de refutar a idéia da natureza de classe das línguas nacionais, se opõe radicalmente à ótica das revoluções na língua, restaurando a continuidade da evolução lingüística.

Ele escreve: "Com efeito, por que é necessário que após cada queda da estrutura existente da língua, sua ordem gramatical e seu fundo lexical essencial sejam destruidos e substituidos por novos, como ocorre comumente com a superestrutura? Para que é necessário que 'água', 'terra', 'montanha', 'floresta', 'pássaro', 'homem', 'caminhar', 'fazer', 'produzir', fazer comércio', etc. sejam designados não por água, terra, montanha, etc., mas por outros nomes? Qual é a utilidade, para a revolução, de tais quedas na língua? A história, em geral, não faz nada de essencial sem uma necessidade particular. Pergunta-se, qual é a necessidade de uma tal derrubada lingüistica, se está provado que a língua existente, com sua estrutura, convém de todo modo à satisfação das necessidades da nova ordem? ${ }^{26,}$

De acordo com Stalin, a língua, enquanto meio de comunicação (sredsvo obšenija) serve igualmente a todas as classes da sociedade e mostra, sob esta perspectiva, uma certa indiferença às classes. Mas os homens, os grupos sociais singulares, estão longe de serem indiferentes à língua. Eles se servem da língua em razão de seus interesses, para impor-lhe um léxico particular, termos e expressões particulares. As classes dominantes primam pela criação de dialetos e jargões sociais (dialetos de classe, jargões de salão).É desta forma que as classes exploradoras manifestam a distância que as afasta do povo e sua aversão pelo povo. ${ }^{27}$

V.M. Alpatov observa que a rejeição da definição marrista sobre a linguagem como superestrutura e do caráter de classe da mesma é apresentada como argumento de modo essencialmente lingüístico: pelas noções de "fundo essencial" da língua e de ordens gramaticais comuns a todas às classes da sociedade, e conservadas após as mudanças de formação. Assim, na língua russa, nem a ordem gramatical, nem o "fundo essencial do vocabulário" teriam mudado. Põe-se fim aos tormentos que os lingüistas russos suportaram para fixar os tratos lingüísticos de uma certa língua instituída após a revolução. Tal ponto de vista é caracterizado por Stalin como primitivo-anárquico. $^{28}$

\section{O dialogismo e o cruzamento de línguas}

O conceito de cruzamento, tomado da biologia, é muito corrente nos debates lingüísticos dos séculos XIX e XX. Assim, a teoria de N. Marr postula que todas as línguas do mundo foram engendradas através de cruzamentos recíprocos a partir de

\footnotetext{
${ }^{25}$ Citado em Alpatov,ibid,p.108.

26, J. Staline, ibid., p.120.

${ }^{27}$ J. Staline, ibid, p.123-124.

${ }^{28}$ Alpatov, Istorija odnogo mifa, ibid., p.185-6.
} 
um número limitado de elementos iniciais( Marr aponta quatro desses elementos: sal, ber, jon, roch). Esses arqui-elementos ou proto-palavras arcaicas, os únicos de que dispunham os homens primitivos, designavam totens de diversas tribos e, na etapa da comunicação primitiva, significavam necessariamente tudo e eram, por conseguinte, indissociáveis de seu contexto de emprego. Marr considera a hibridação como um fenômeno extremamente positivo, que está na origem da riqueza lingüística atualmente existente. A idéia de cruzamento das línguas é fundamental no trabalho de Marr, a partir do ano de 1899( ano de sua defesa de tese de magistério).

Nesse trabalho, ele afirma a origem dupla ou cruzada do armênio. Essa hipótese, postulando o armênio como produto do cruzamento "jafético" (na linguagem de Marr: "relativo às línguas caucasianas") e indo-europeu foi forjada para dar sustentação ao parentesco entre o georgiano e o armênio, sem refutar o fato reconhecido do pertencimento do armênio à família indo-européia. Marr relaciona o cruzamento de línguas com o cruzamento de etnias: segundo ele, o povo armênio é de origem jafética e as classes dominantes descendem dos conquistadores indo-europeus. As conotações de engajamento anti-colonial e anti-eurocentrista de Marr já aparecem bastante nítidas nessa conceituação. Mais tarde, Marr irá afirmar o caráter de cruzamento de todas as línguas. A idéia de cruzamento, permitindo ligar qualquer língua às línguas caucasianas torna-se fundamental para a lingüística marrista. ${ }^{29}$

Segundo observação dos lingüistas, a hipótese sobre a origem cruzada do armênio deve-se ao fato de que essa língua possui em seu léxico antigo um certo número de unidades de origem não-indo-européia. Para explicar tais fenômenos, a lingüística do séc. XIX propôs a noção de substrato (H. Schuchardt), definido como um conjunto de sobrevivências na língua de uma dada etnia que mudou a língua e os traços de influência da antiga língua ${ }^{30}$. Por outro lado, a esterilidade dos híbridos, atestada no mundo animal, parece influenciar o imaginário de Stalin no momento de publicação de seu texto sobre lingüística geral. Para ele, o corpus da língua nacional deveria ser puro, não suportar a hibridez e nem se constituir por cruzamento. Lembre-se que também o próprio Lênin, em seus escritos sobre a arte, mostra-se obcecado pela idéia de pureza da língua russa, ele se mostra purista, em relação às questões lingüísticas, e luta radicalmente contra os empréstimos e decalques ocidentais, o que prepara o terreno para as vastas campanhas contra os cosmopolitas na URSS de Stalin.

Pode-se comparar os argumentos a favor e contra o cruzamento das línguas, desenvolvidos por Bakhtin, aliás Volochinov, em "Marxismo e Filosofia da Linguagem", e por Stalin, em "Marxismo e Problemas de Lingüística". Para Volochinov, a metáfora do cruzamento das línguas aparece no contexto inesperado da luta de classes. Volochinov começa pela tese de que a refração do ser no signo ideológico é determinada pelo cruzamento de interesses sociais diferentemente orientados nos limites do mesmo coletivo de signos (znakovyj kollektiv), isto é, pela luta de classes.Segundo ele, a classe não coincide com o coletivo de signos, isto é, com o coletivo que utiliza os mesmos signos de comunicação ideológica. Assim,

\footnotetext{
${ }^{29}$ Alpatov, ibid, p.18.
}

${ }^{30}$ Alpatov, ibid,p.18. 
diversas classes se utilizam da mesma língua. Em conseqüência, diversos acentos se cruzam em cada signo ideológico. O signo torna-se o palco da luta de classes ${ }^{31}$. Esse cruzamento de acentos dentro do mesmo signo é considerado por Volochinov, aliás Bakhtin, como condição de "vida" do signo, como uma instância que lhe atribui , de fato, o estatuto de ser orgânico vivo. Volochinov escreve:

" Na realidade, é apenas graças a esse cruzamento de acentos que o signo é vivo e móvel, capaz de desenvolver-se. O signo extraído da luta tensa de classes, que se encontra do outro lado da luta de classes, será inevitavelmente atrofiado ${ }^{32}$, degenerará em alegoria, tornar-se-á objeto de compreensão filológica e não de interpretação social viva. A memória histórica da humanidade é cheia de tais signos mortos que não conseguem ser a arena de confrontação de acentos sociais vivos[..]Mas é exatamente aquilo que torna o signo ideológico vivo e mutável, o mesmo que faz dele o meio de refração e de deformação do ser. A classe dominante visa atribuirão signo ideológico um caráter eterno, destituído de classe, e atenuar ou recalcar a luta de acentos sociais que ocorre nele, para considerar um acento único(monoakcentrism.) ${ }^{33}$

Assim, estabelece-se o diálogo entre a tese de Volochinov e a tese de Stalin a respeito do caráter destituído de classe da língua nacional. Volochinov insiste a respeito do "caráter dialético" interno do signo que, segundo ele, manifesta-se somente em épocas de crise social e de transformações revolucionárias. Na condições habituais da vida social, essa contradição situada em cada signo ideológico não pode se resolver completamente, porque o signo ideológico, na ideologia acabada e dominante, é, em certa medida, sempre reacionário. Pode-se dizer que ele tenta estabilizar o momento precedente do fluxo dialético, do devir social, acentuar a verdade de ontem como verdade de hoje ${ }^{34}$. Assim, na ideologia estável e dominante o signo ideológico é reacionário, está "morto", pois falta-lhe o cruzamento de acentos sociais.

Volochinov, aliás Bakhtin, retoma a idéia de cruzamento como instância vivificante, quando aborda o problema do papel histórico da <palavra estrangeira > para a linguagem. Ele define a lingüística como um fenômeno engendrado pela " palavra estrangeira" e fixado por essa < palavra estrangeira $>$. A lingüística, ela própria, produto da "palavra estrangeira" não pode entender o verdadeiro papel da palavra estrangeira na história da língua e da consciência da linguagem. Volochinov baseia-se na idéia de cruzamento de línguas de Nicolai Marr como fator essencial da evolução da língua e de sua origem. Ele cita um longo trecho de Marr, em que o cruzamento, em geral, é definido como fator de aparição de diversas espécies e tipos e de suas condições de formação. Para Marr, a língua primitiva não existe jamais. A língua surge como manifestação das necessidades econômicas e comunicativas das tribos e é sempre um depósito de aspectos sociais das tribos ${ }^{35}$. Segundo Marr, da mesma forma que os estados sociais resultam das tribos através de cruzamentos, as línguas das

\footnotetext{
${ }^{31}$ Bakhtine, Tetraloguija, ibid, p.317.

${ }^{32}$ Literalmente: zakhireet, (desprezível, enfermo)

${ }^{33}$ Bakhtine, Tetraloguija, p317.

${ }^{34}$ Bakhtin, Tetraloguija, p.317-18.

${ }^{35}$ Bakhtine, ibidem, p.370.
} 
tribos, e, mais ainda, as línguas nacionais constituem-se em tipos cruzados de línguas. Formam-se por cruzamento, a partir de elementos simples, cuja combinação constitui a língua como um todo. A análise paleontológica estabelece os nomes dos elementos iniciais das tribos. A questão da origem da língua se reduz ao problema da aparição destes elementos, os nomes das tribos. ${ }^{36}$

A conclusão implícita de Volochinov, aliás Bakhtin, é também bastante explícita: o cruzamento de acentos de tipo ideológico ou dialógico é a própria encarnação da vida, é uma condição fundamental da vida da palavra ou do signo lingüístico. Esta ideologia que anima a palavra, que torna viva a oposição vida/morte penetra no texto e coloca os acentos. O "ideológico" o "social" tornam-se sinônimos do vivo, do orgânico e os termos "lingüístico", "abstrato", "formal" são sinônimos de morte, do não-orgânico. Assim, de acordo com Volochinov, a dissociação entre a língua e seu preenchimento ideológico é um dos erros mais profundos do objetivismo abstrato. Sua reprovação à "lingüística abstrata" reside "na visão, prática e teórica, do estudo das línguas estrangeiras mortas conservadas nos documentos escritos". Volochinov, aliás Bakhtin, afirma a respeito da "consciência lingüística do mundo europeu" : "É sobre o cadáver dessas línguas escritas que a consciência formou-se e morreu. Todas as categorias, as abordagens essenciais e os hábitos dessa consciência foram elaborados pela reanimação desses cadáveres. ${ }^{37,}$

Volochinov, aliás Bakhtin cita Marr, a respeito da lingüística indo-européia, quando afirma que ela se desenvolveu a partir de "formas petrificadas" (okocenelykh) das línguas escritas e a partir do "enunciado monológico morto ${ }^{38 "}$. A tradição sobre esse trabalho lingüístico sobre as línguas estrangeiras mortas e os monumentos escritos leva a uma compreensão da linguagem de tipo passiva." Qualquer teoria da significação que toma a palavra como tema é inteiramente impregnada pela falsa idéia da compreensão passiva de uma forma de compreensão da palavra em que uma resposta ativa a esta é, de antemão, essencialmente excluída". Volochinov, aliás Bakhtin define a "língua da consciência lingüística" como a "língua morta", escrita, estrangeira $^{39}$.Como conseqüência disso, a tradução literal, dita de tipo lingüístico está associada, conforme Volochinov, à "compreensão morta".

Lembremos que Marxismo e Filosofia da Linguagem foi produzido em uma época em que a lingüística marrista, baseada na tese do cruzamento das línguas, começa a reinar em rex solus nesse campo. Alguns anos após, Marr e sua teoria serão onipresentes e todo poderosos. Essa referência à lingüística oficial de Marr fornece uma das fontes de inspiração conceitual do Círculo de Bakhtine. Essa fonte, que os estudos bakhtinianos contemporâneos não costumam levar em conta,fornece elementos suplementares a respeito do conceito maior de Bakhtin e de seu Círculo, o conceito de dialogismo ou polifonia. Uma outra coincidência conceitual importante, entre as formulações de Marr e Volochinov, aliás Bakhtin, é o acento anti-filológico diante da necessidade de a

\footnotetext{
${ }^{36}$ Bakhtine, ibid, p.371.

${ }^{37}$ Bakhtine, ibid. p.364-5.

${ }^{38}$ Bakhtine, ibidp.366.

${ }^{39}$ Bakhtine, ibid, p.367.
} 
lingüística abordar "as línguas vivas”, principalmente as línguas sem escrita. O fato de que as línguas que não possuem escrita não tenham constituído um objeto de estudo para a lingüística indo-européia é considerado, por Marr, como resultado de uma "escolha de classe" do material de análise, visando a um estudo da" própria língua de classe", suposta como língua nacional. ${ }^{40}$

Da mesma forma, Marr atribui a toda lingüística indo-européia a idéia "racista" do primitivismo e da inferioridade das línguas não-flexionais. Ao acusarem a lingüística histórica e comparada de associar línguas e raças, Marr e seus discípulos a acusaram por dividir a humanidade em raças inferiores e superiores e de estar aparentada à teoria racista do nazismo. ${ }^{41}$ Os discípulos de Marr interpretaram as diferenças de ordem gramatical entre as diversas línguas, tais como são concebidas pela lingüística histórica e comparada, como um postulado de propriedades fixas, pertencendo aos diversos povos. Segundo Marr, somente os missionários e os militares estudavam "as línguas vivas" no ocidente, enquanto a lingüística indo-européia não fez nada para isso. ${ }^{42}$ Marr e seus discípulos exigiam que o trabalho de pesquisa sobre as normas da língua escrita fosse substituído pelo estudo "das normas da fala viva das massas" e das "línguas sem escrita dos povos explorados". As línguas sem escrita ou providas de um sistema de escrita recente deveriam até mesmo ocupar o lugar das línguas clássicas na escola e na cultura. Essa exigência coincidiu com a tarefa de "edificação lingüística"(jazykovoje stroïtelsvo), isto é, com a criação de alfabetos para as línguas sem escrita e as literaturas nacionais nos anos 20. A hostilidade de Marr em relação ao estudo dos textos antigos e das "línguas de cultura" responde ao programa ideológico do regime. A "língua viva"a nova língua de uma nova sociedade deveria refletir as mudanças radicais no pensamento, e a "língua dos proletários" deveria substituir a língua dos intelectuais e dos aristocratas ${ }^{43}$.

A conceituação política da"língua viva" foi apresentada pelo marrismo como uma manifestação da revolução na língua, integrando a revolução cultural. Dentro desse quadro, Marr exigia, não reformas parciais no domínio da ortografia ou da gramática, mas a reconstrução radical de todo universo da "superestrutura", a mudança das normas da língua, a passagem da língua "pelos trilhos da palavra das massas". Essa revolução na língua afirmava-se como uma elevação da mesma e da consciência a um patamar superior do "desenvolvimento por estágios" da fala humana que refletisse a "criação revolucionária" na formação de uma nova língua ${ }^{44}$. O motivo da "criação revolucionária" na linguagem não é próprio da teoria marrista: Marr tinha um precursor marxista muito importante, Paul Lafargue, que, em seu livro sobre o estatuto da língua francesa antes e depois da revolução, publicado em 1930, afirma várias vezes que as novas circunstâncias políticas exigem uma nova língua, da mesma forma que a língua latina, durante a segunda guerra púnica, dividiu-se em uma língua aristocrática e uma língua plebéia. No entanto, Lafargue não considera o caráter de

\footnotetext{
${ }^{40}$ Alpatov, Istorija adnogo mifa, ibid, p.60.

${ }^{41}$ Alpatov, ibid, p.60-61.

${ }^{42}$ Alpatov, ibid, p.62,63.

${ }^{43}$ Alpatov, ibid,p.65,66.

${ }^{44}$ Alpatov, ibid,p.65.
} 
classe como propriedade de qualquer língua: afirma, em particular, que um dos resultados da Revolução Francesa foi o fato de que a língua da burguesia teria se transformado em língua de uso comum ${ }^{45}$.

Vinte anos após a publicação do livro de Volochinov, aliás Bakhtin, Stalin, em seu texto sobre lingüística geral, apresenta uma atitude muito diferente em relação ao cruzamento de línguas. Stalin declara ser falsa a opinião de que o cruzamento das línguas possa dar nascimento a uma nova língua pela explosão, pelo salto da qualidade antiga à qualidade nova ${ }^{46}$. Alpatov nota que, no que diz respeito ao problema do cruzamento e da interação das línguas, Stalin tendo aceito o "termo de cruzamento de Marr", rejeitou, de fato, seu conteúdo, voltando às formulações habituais feitas pelos neo-gramáticos. Segundo Stalin, ao longo do cruzamento das línguas não ocorreu nem explosão revolucionária, nem formação de uma terceira língua. A língua triunfante permanece a mesma, mas inclui certos elementos da língua vencida. Alpatov vê nisso o surgimento do conceito de substrato. Essa abordagem reconhece implicitamente o parentesco das línguas. ${ }^{47}$

De acordo com Stalin, o cruzamento das línguas não é um ato único à semelhança da explosão,mas um longo processo que dura centenas de anos. Seria errado pensar que a partir do cruzamento das línguas derivaria uma língua nova, uma terceira língua que seria qualitativamente diferente das duas primeiras. Na realidade, quando ocorre um cruzamento entre línguas, uma das duas acaba vencendo.Ela conserva sua ordem gramatical, seu fundo lexical essencial e continua se desenvolvendo conforme as leis internas de seu desenvolvimento, enquanto a outra língua perde sua qualidade e morre gradualmente. Portanto, o cruzamento das línguas não cria uma nova língua, mas conserva uma das línguas e lhe dá a possibilidade de desenvolvimento segundo suas leis internas. ${ }^{48}$

Ao mesmo tempo, há uma fecundidade recíproca das línguas. A língua dominante assimila, através do mecanismo dessa dominação, os melhores traços das línguas vencidas.Da mesma forma, as línguas nacionais da URSS se enriquecem, constantemente, constantemente, graças ao contato com a língua russa. Esta última, por sua vez, se enriquece graças aos contatos com as línguas nacionais. Portanto, há dois tipos de coexistência - orgânica e não-orgânica. Os empréstimos ocidentais, neologismos, barbarismos, "jargão de salão"(associado principalmente à influência ocidental) não são nem harmoniosos nem orgânicos, e, enquanto tais, têm de ser liquidados. A coexistência orgânica pressupõe relações fecundas: portanto, há línguas que sabem coexistir harmoniosamente. Parece que o espaço unido, a continuidade espacial, é o que garante a organicidade dessa coexistência. Pois é devido ao fato de ter conservado "sua ordem gramatical e o fundo lexical essencial", isto é, um núcleo interno puro, que a língua pode progredir e desenvolver-se segundo as leis internas de seu desenvolvimento. Daí a conclusão de Stalin de que a teoria do cruzamento das

\footnotetext{
${ }^{45}$ Alpatov, ibid,p.72-73.

${ }^{46}$ Staline,ibid,p.142.

${ }^{47}$ Alpatov, ibid,p.185,186.

${ }^{48}$ Staline, ibid.,p.142,143.
} 
línguas não pode estudar as leis internas do desenvolvimento da língua, pois não tem acesso $^{49}$ a elas.

Parece que essa lei interna e íntima da língua, esse "fundo essencial" de que Stalin fala, é análogo ao "genótipo" no sentido biológico. O cruzamento sendo exilado é a absorção gradativa e orgânica das línguas dominadas por uma língua dominante que é introduzida como o único mecanismo da evolução lingüística. Com efeito, segundo Stalin,:"a ordem gramatical elaborada ao longo das épocas, que entrou no sangue e na carne da língua, muda ainda mais lentamente do que o fundo lexical essencial".A língua muda com o tempo, no sentido de que ela se aperfeiçoa, aperfeiçoa e define suas regras, se enriquece com novas regras.Mas os fundamentos da ordem gramatical conservam-se por muito tempo porque, como a história mostra, eles podem ser úteis à sociedade durante séculos ${ }^{50}$. Esses dois fatores - ordem gramatical da língua e seu fundo lexical essencial - constituem o fundamento da língua e a essência de sua especificidade. $^{51} \mathrm{O}$ desenvolvimento da língua produz-se, não pela destruição da língua já existente e pela construção de uma nova, mas pelo desenvolvimento e aperfeiçoamento dos elementos fundamentais da língua existente. Essa passagem de uma qualidade de língua a uma outra não se dá por explosão, mas pela acumulação gradativa e lenta de elementos de uma nova qualidade, pela atrofia(otmiranije) gradativa dos elementos antigos. ${ }^{52}$

Essa divergência a respeito do cruzamento das línguas entre Marr, Volochinov, aliás Bakhtin, e Stalin pode expressar-se nas categorias de genótipo e fenótipo, propostas pelo biólogo alemão August Weismann. O genótipo é definido como um fundo hereditário imutável e transmissível através das gerações, enquanto o fenotexto é entendido como sendo a realização individual de um organismo a partir desse fundo genético. O cruzamento como dispositivo da evolução pressupõe um fundamento vitalista, pois essa idéia atribui uma força vital, uma força de fecundação à totalidade do organismo vivo. Trata-se de um dispositivo "fenotípico", no sentido em que se considera qualquer parte do ser orgânica, enquanto portadora de potencial hereditário reprodutivo. A perspectiva "genotípica" postula o caráter imutável dos traços hereditários, pois todas as características geneticamente pertinentes estão concentradas em células especializadas do organismo, as quais se desenvolvem conforme suas próprias leis intrínsecas e de maneira autônoma, em relação aos fenômenos externos.

Traduzido em termos biológicos, o texto de Stalin, ao contrário das afirmações de Marx e de Volochinov, aliás Bakhtin, adota a perspectiva continuísta ou genética. $\mathrm{O}$ genótipo da língua nacional aparece como fundo estável e não submetido a mutações ou mudanças bruscas imprevisíveis. Por outro lado, os conceitos de cruzamentos de línguas, segundo Marr e Volochinov, aliás Bakhtin, colocam o fenótipo, isto é, o organismo vivo já realizado, como motor da evolução e como instância de engendramento de novos organismos lingüísticos.

\footnotetext{
${ }^{49}$ Stalin, ibid, p.143.

${ }^{50}$ Staline, ibid.,p.138.

${ }^{51}$ Staline,ibid,p.138.

${ }^{52}$ Staline,ibid.,p.139, 140.
} 


\section{A Escrita Dialógica}

Comentando a idéia de Volochinov acerca do "discurso reportado"(compreendido como o "discurso no discurso, a enunciação na enunciação" mas, ao mesmo tempo, um discurso sobre o discurso, uma enunciação sobre a enunciação), J. Peytard observa que esta concepção se fixa pela meta de "indicar os pontos onde, no discurso, vêm se inscrever os discursos de outros, mas postulando que tal operação é a de uma escrita entre dois tecidos que interagem". ${ }^{53} \mathrm{O}$ comentário traduz muito fielmente o pensamento de Volochinov-Bakhtin: pois é preciso, com efeito, um procedimento de escrita equivalente aos procedimentos biológicos em voga na URSS dos anos 20-30. O centro de gravidade do dialogismo do Círculo de Bakhtin se acha na imagem orgânica da interação dos tecidos orgânicos escritos. Organismo receptor da escrita(discurso autoral) e discurso antecipado(discurso reportado, discurso do outro, as escritas) se unem na unidade do organismo escrito. ${ }^{54}$

Esta metáfora vegetal, originária do campo da "agrobiologia" à soviética não se suspende lá. Para teorizar "o discurso no romance" Bakhtin recorre ao termo "hibridação". De acordo com Peytard, a "hibridação" é definida como "mistura de duas linguagens no interior de um único enunciado" 55 . O dialogismo bakhtiniano colocou como próprio do gênero do romance fundar-se, de fato, sobre esta qualidade particular da palavra ou do discurso misto, onde a instância heterogênea se expressa por diversas estratégias de incorporação. Esta instância transplantada e recriada é "a imagem da linguagem" do outro no romance, remetendo a três categorias principais: a hibridação, a interrelação dialógica das línguas, os diálogos puros. ${ }^{56}$

O termo hibridação não é o melhor termo para exprimir o topos bakhtiniano por excelência, cujo paradigma é introduzido pelo conceito de "palavra bivocal", de modo que, pelo tema da "imagem da língua" tal como o estilo indireto livre: a palavra sobre a palavra, o discurso sobre o discurso, o discurso reportado,etc.... É a formulação mais clara do mecanismo essencial da constituição da cadeia discursiva do romance, mecanismo cuja imagem portadora do simbolismo antigo mais próxima parece ser a fecundidade do cruzamento de seres orgânicos. Com efeito, o "vai e vem entre o locutor e sua linguagem"57 apóia-se sobre uma metáfora orgânica, onde a hibridação é sinônima de fertilidade ou de fecundidade. ${ }^{58}$ Esta nova forma discursiva que é

\footnotetext{
${ }_{53}^{53}$ J. Peytard, p.38,39.

${ }^{54}$ Peytard acrescenta que $0<$ ato de inserção, citação[...] supõe a atividade do sujeito reportante, que o discurso objetivado não é em nada passivamente mecânico, e que o discurso selecionado e escrito não se dá sem influência sobre o seu receptor[...],reportar um discurso externo é extrair um segmento do discurso ambiente e o ato de extração obriga a julgar, pesar e avaliar - como ocorrerá com o ato de inserção.(Peytard, ibid.,p.39).

${ }^{55}$ Peytard, ibid., p.78.

${ }^{56}$ Citado em Peytard, ibid., p.78.

${ }^{57}$ Peytard, ibid., p.123.

${ }^{58}$ Peytard resume este dispositivo como segue: cada personagem, dispondo de um registro pessoal, ao qual ele se identifica, derivando do fato de que, no romance, se instaura uma variedade de línguas. Ele se produz, então,do autor aos múltiplos personagens, dentro dos quais se refratam suas intenções, uma troca sob influência recíproca. O discurso do autor não se realiza paralelamente ao das personagens que ele
} 
colocada como uma forma romanesca ou polifônica, ou ainda dialógica, é o produto da interação proliferante dos discursos"exteriores", onde esta alteridade, esta heterogeneidade, é definida, positivamente, como uma condição necessária e como garantia "anti-incestuosa" da transformação da palavra. ${ }^{59}$

O discurso do romance e seu "potencial polifônico" são conceituados na obra de Bakhtine pelo viés do que definiríamos como "escrita dialógica". Com efeito, a presença do outro, da heterogeneidade no discurso, é marcada por uma espécie de "escritura", por uma operação equivalente à transplantação de um tecido orgânico sobre outro corpo orgânico, portador de sua própria autonomia vital. Na episteme soviética dos anos 20-30 este mecanismo de enxerto está longe de ser uma novidade. Tal procedimento é oriundo de uma tradição materialista russa bem ancorada: a biologia de Mitchourine e de Tymiriazev. Ela se situa também no contexto bastante ativo da agrobiologia. De Tophime Lyssenko. A técnica de enxerto, herdada de Mitchourine, jardineiro e horticultor amador, apaixonado pela hibridação das diferentes árvores frutíferas, recebeu de Lyssenko uma interpretação teórica, de acordo com a qual pelo enxerto pode-se obter "híbridos" que possuiriam os caracteres hereditários das espécies biológicas participantes. ${ }^{60}$ Para Lyssenko, os "híbridos produzidos por enxerto" ou os “híbridos vegetativos" não poderiam quase diferençarse dos híbridos obtidos pela via habitual do cruzamento sexual. O lyssenkismo considera que se pode transmitir o hereditário pela técnica do enxerto sem utilizar a via dos cromossomos e de ácidos nucléicos ${ }^{61}$.

De acordo com Lyssenko, a prática da hibridação recebeu a interpretação "antigenética"com vistas ao combate da teoria cromossômica da hereditariedade, sobretudo a idéia da existência de "uma substância hereditária distinta do corpo habitual" "2 . Para ele, as propriedades hereditárias passam do sujeito ao cruzamento e, inversamente, sem mudar os cromossomos dos núcleos celulares. Lyssenko escreve: "as matérias plásticas elaboradas pelo organismo cruzado e o organismo de suporte, da mesma forma que os cromossomos são as mesmas, não importa qual partícula do

acompanhará à distância, mas suas palavras penetram a palavra autoral, como uma"língua estrangeira" que vem retocá-la. A interação dos discursos se opera. Discurso direto das personagens, mas também discursos indiretos se encadeiam no contexto discursivo do autor, e esta combinação toma forma de um jogo complexo de enunciações que intensifica o plurilingüismo romanesco.

${ }^{59}$ No que concerne à polifonia e dialogismo bakhtiniano, J.M. Schaeffer formula assim o "núcleo central da teoria bakhtiniana do romance": " a) o romance é a expressão literária fundamental da idade moderna. Tese histórico-ontológica baseada na distinção entre uma sociedade orgânica-unitária e uma sociedade fragmentária-plural. Esta tese não é simplesmente sócio-histórica, mas também ontológica: a fragmentação estrutura a subjetividade do homem pós-antigo. Reconhece-se, evidentemente, a dicotomia romântica entre a objetividade da Antigüidade e a subjetividade da modernidade.b) o romance é um devir eterno, ele é infinito. Esta infinitude está colocada em dois aspectos do romance: a ausência de todo cânone genérico e a autocrítica permanente;c) o romance é tendencialmente universal. Bakhtin não emprega este termo, mas ele se torna necessário quando o romance se faz combate para a supremacia e para a desagregação/integração paródica de outros gêneros".A universalidade pode ser designada, de acordo com Bakhtin, prurilingüismo, termo que se refere ao fato de que o romance tende a integrar todos os outros discursos sociais.(J.M.Schaeffer. O nascimento da literatura. A teoria estética do romantismo alemão. Paris,1983, p.89-90).

${ }^{60}$ D. Buican,Lyssenko e o lyssenkismo(1988,p.49).

${ }^{61}$ Buican, ibid, p. 50,51.

${ }^{62}$ Buican, ibid, p.51. 
corpo vivo, possuem propriedades raciais, uma certa hereditariedade que lhes é própria[...] . É errôneo afirmar que a hereditariedade é a propriedade exclusiva de uma substância distinta, especial, qualquer que seja a parte do organismo ou da célula onde se localiza. Toda parcela viva, do mesmo modo que toda gota viva do corpo(se esta última é líquida) possui propriedades hereditárias, quer dizer, a propriedade de exigir condições relativamente definidas para viver, crescer e se desenvolver." 63 .

A idéia de hibridação vegetativa em Lyssenko consiste em dizer que "cada gota de substância viva transmite a hereditariedade, que não teria, portanto, o substrato material específico" "64. Lyssenko postula a fusão e a assimilação mútua de duas células no processo sexual. Isto vem de encontro à concepção "idealista" da genética contemporânea (Mendel, Morgan) de acordo com a qual "os fatores hereditários guardam sua independência no interior da própria célula e não se fundem uns aos outros". ${ }^{25}$ Para Lyssenko, o processo de fecundação é dotado de um dispositivo materialista dialético, ele está fundado sobre o mecanismo da contradição dialética. Em conseqüência, se a"hibridação vegetativa e a hibridação sexual são fenômenos da mesma ordem", devem, pois, ter uma base comum. Essa base comum é que a hibridação vegetativa e a hibridação sexual são processos, onde os elementos de cruzamento se assimilam uns aos outros, dando nascimento a um produto híbrido. ${ }^{66}$

A agrobiologia de Lyssenko concentra-se sobre a interação de elementos orgânicos e inorgânicos, sobre as trocas entre os organismos e o meio, bem como sobre a assimilação recíproca destas duas instâncias. O procedimento de cruzamento, onde um elemento de um organismo jovem se encontra implantado sobre o caule de uma planta adulta, e onde o novo cruzamento é compelido "a assimilar o mais possível as substâncias nutritivas elaboradas pela variedade da qual se quer transmitir as propriedades, evoca o cuidado pedagógico da reeducação orgânica sob a influência do meio ambiente". ${ }^{67}$ É preciso uma pedagogia natural que se organize de acordo com o modelo da nutrição vegetal. $\mathrm{O}$ cruzamento é separado dos elementos brutos, ele não recebe senão os produtos elaborados pelo organismo de suporte e é por este canal de assimilação intrínseca que passa a transmissão das características hereditárias desejadas.

\footnotetext{
${ }^{63}$ Citado em Buican, p.51,52.

${ }^{64}$ Buican, ibid,p.55.

${ }^{65}$ Buican, ibid,p.58.

${ }^{66}$ Citado por Buican, ibid., p.58.

${ }^{67}$ As outras implicações deste novo vitalismo revolucionário se encontram formuladas como segue: ...Assim, portanto, as substâncias plásticas do sujeito, elemento exterior(sumos) em relação ao enxerto, tornadas, por assimilação, parte do corpo, modificam as propriedades hereditárias deste último[...], os elementos da natureza inerte do meio onde se encontram as tornam-se, por assimilação, muitas vezes forçados, partes constitutivas do corpo vivo, tornando-se vivos e adquirindo propriedades hereditárias[...], uma vez assimilados pelo corpo vivo, os elementos brutos da natureza deixam de ser o que eram, não somente pelo aspecto exterior, mas mesmo do ponto de vista estritamente químico. Eles adquirem, por outro lado, uma afinidade bioquímica muito acusada, eles experimentam uma atração pelos elementos exteriores, antes de serem assimilados pelo corpo vivo, antes de tornarem-se, eles próprios, de certa forma vivos (citado em Buican, ibid, p.55.
} 
Observa-se uma idéia homóloga sobre a interação de tecidos orgânicos na visão de Goethe a respeito da metamorfose das plantas. Em seus comentários sobre os escritos botânicos de Goethe, Rudolf Steiner destaca a diferença entre o botão e a planta, onde ambos contêm, entretanto, a virtualidade de sua realização ou de seu desdobramento "a semente tem como terreno imediato de desenvolvimento a terra, enquanto o botão é, em geral, uma planta formada de uma planta". O botão, cuja formação corresponde à interrupção do crescimento, é um novo estágio da vida vegetal, estrato tornado visível. ${ }^{68}$ A semente e o botão situam-se, portanto, em momentos diferentes no ciclo vegetal, momentos que correspondem às formas de diástole e sístole.

Por outro lado, se a semente está em contato imediato com o meio ambiente e recebe os sumos nutritivos diretamente deste meio, o botão, por outro lado, é nutrido de modo "mediatizado". O modo de nutrição do botão supõe o conjunto dos fenômenos de crescimento vegetal - uma intensificação ou uma"progressão sobre uma escala espiritual"(steigerung), uma elaboração crescente, um afinamento dos tecidos vegetais, e Steiner fornece a explicação. Se os órgãos em contato com a terra, como a semente, são imediatamente dependentes do meio exterior, inorgânico, os órgãos afastados deste meio, como os botões, retiram sua nutrição dos elementos orgânicos que já os precedem. E Steiner acrescenta:“Assim cada um recebe uma nutrição já preparada pelo precedente"69. O próprio Goethe explica como segue o fundamento orgânico, nutricional, do mecanismo de intensificação: "Um vínculo superior, nascido do precedente e recebendo os sumos pelo seu intermediário, deve recebê-los mais afinados, mais filtrados; ele deve aproveitar-se também da ação exercida entre os tempos, pelas folhas, desenvolver-se com mais apuro e fornecer às suas folhas e a seus olhos seivas mais purificadas". 70

A imagem morfológica da intensificação ou da "progressão sobre a escala espiritual" oriunda dos escritos botânicos de Goethe é, portanto, facilmente discernível por detrás das formulações da "nova biologia proletária" de Lyssenko.

A prática de cruzamento, procedimento-mestre desta teoria, porta, então, a marca da tradição orgânica da formação, da qual ela é herdeira espiritual ${ }^{71}$. Poder-se-ia tirar uma conclusão sobre a filiação morfológica do dialogismo de Bakhtine, bem como de sua teoria do romance e de sua "translingüística". Estando, de um lado a "hipóstase

\footnotetext{
${ }^{68}$ J. Goethe. A metamorfose das plantas, 1975:p.48..

${ }^{69}$ Goethe, ibid,p.49.

${ }^{70}$ Citado por R. Steiner em Goethe, ibid., p.49.

${ }^{71}<$ Escrita $>$, $<$ antecipação $>$, $<$ germe $>$, <engendramento $>$, o pensamento textológico veicula este imaginário $<$ biológico $>$ oriundo das ciências naturais, tão decisivas para o imaginário conceitual a partir do séc. XIX. O fato de essas conotações parecerem permanecer em vigor, testemunha, a nossos olhos, da sobrevivência tenaz da epistemologia do séc. XIX, na qual o imaginário orgânico determina o trabalho do conceito em campos fortemente diferentes.. É uma testemunha da força de quaisquer figuras epistemológicas nascidas no seio deste período, onde figura o organismo. A colocação em jogo das dimensões do geno-texto e do feno-texto lembra necessariamente a distinção entre fenótipo e genótipo, introduzida em biologia pelo geneticista dinamarquês Wihelm Johansen(1857-1927) e pelo biólogo alemão August Weismann (1834-1914). A noção de geno-texto (Saumjan Kristeva) revela, em particular, sua filiação com as noções de escrita, antecipação e de genotipo.
} 
ontológica" do estilo pictorial de de H. Wolfflin, este dominante "polilogos" da obra de Bakhtin é oriundo da metáfora de hibridação produtiva.

A ontologia do romance exposta nestes escritos sobre o gênero romanesco ${ }^{72} \mathrm{e}$, em geral, a ontologia da "palavra bivocal", da palavra dialógica na obra de Bakhtin e os autores de seu círculo, funda-se sobre o substrato morfológico alemão, sobre a tradição de formação, com a idéia de "forma interna". Os "gêneros da palavra" e o projeto da "translingüística", da "poética social" parecem explorar diversas ramificações deste projeto essencialmente romântico do "absoluto literário"73 , mas também o projeto morfológico fundado sobre a idéia do crescimento orgânico das "formas naturais".

\section{Continuidade versus ruptura ou após a revolução, evolução}

Já que o "fundo essencial" da língua nacional é imutável, é preciso combater o cosmopolitismo e a política cultural do regime, visando, por conseqüência, a restauração da pureza da língua nacional.

Faz-se necessário o retorno às origens populares ou autênticas da língua pela ultrapassagem dos "dialetos" e dos "jargões de classe". A política lingüística será, portanto, a terapia da língua, sua depuração dos empréstimos ocidentais, dos "jargões de salão" e do formalismo estéril.

O texto de Stalin restaura a continuidade entre o pensamento e a linguagem, entre a nação e as classes. O chefe do Partido sente a necessidade de re-estabelecer esta continuidade que é a condição necessária da homogeneidade do processo histórico. Uma tal ótica muda o estatuto dos estágios ou das formações sócio-históricas. A ruptura não é mais um elemento constitutivo desse quadro do mundo, são as rupturas dialeticamente assimiladas que se inserem no todo orgânico do processo universal. Nos anos 20, em vista da Revolução Internacional (de acordo com a concepção de Trotsky), os lingüistas soviéticos transpõem para o cirílico o alfabeto latino.

A concepção stalinista da construção do socialismo em um único país inaugura a russificação dos povos da URSS: o cirílico é imposto aos povos muçulmanos.

\footnotetext{
${ }^{72}$ De acordo com Schaeffer, uma das grandes questões postas por essas teorias é, a saber $<$ em que a teoria do romance esclarece os problemas concretos que encontra a análise histórica das tradições romanescas ou ainda, a ontologia romântica apreende um real literário? (Schaeffer, ibid., p.90).

${ }^{73}$ J.M. Schaeffer observa a respeito desse tema:< é inegável que as noções de origem romântica, tais como a auto-crítica reflexiva, a mistura de gêneros(plurilingüismo), o dialogismo, a integração-dissolução genérica, etc... intervêm de maneira central nas pesquisas de Bakhtin: por outro lado, não é menos inegável que essas pesquisas não chegam nulamente a fundar o componente histórico-ontológico dessas noções(componente que precisamente as constitui em Teoria do Romance)>.(Schaeffer,ibid.,p.91). A Teoria do Romance é, de fato, uma teoria da narrativa abortada. Abortada, porque há uma ausência de congruência entre o real a que se visa apreender e o fechamento conceitual que é posto em evidência[...] Não há o real literário que aprisione, que resista, aos males da teoria, não retendo senão fantasmas[...] , a Teoria do Romance de Bakhtin é a hipóstase ontológica da tradição romanesca do estilo pictorial[...]. Assim, abre-se o campo de uma outra leitura da Teoria do Romance[...], uma leitura não mais teórica[...], mas sobretudo romanesca[...] o romance do romantismo $>$ (Schaeffer,ibid.., p.93).
} 
A intervenção de Stalin leva adiante as idéias de patriotismo soviético, ancoradas na tradição essencialmente estática e "grande-russa". Uma boa razão desta intervenção, provavelmente, tenha sido a necessidade política interna da União Soviética, de então, de "uma nova comunidade histórica" sem classes antagonistas, de acordo com a Constituição soviética, pois como salienta Stalin, uma das características da nação é a comunidade da língua. A tese da continuidade histórica, da ausência de um salto de tipo revolucionário e da inutilidade da teoria da evolução por saltos dentro de uma sociedade sem classes pode servir para fixar (no nunca) o monopólio político do estado comunista.

$\mathrm{O}$ texto staliniano definiu a língua nacional como um consenso válido para a "sociedade toda" para "todo o povo". A língua, concebida como meio de comunicação fora da distinção de classe, reforça a tese da Constituição soviética de 1936. De acordo com esta última, as classes exploradoras tinham sido eliminadas: a sociedade, onde não existiriam senão duas classes, trabalhadores e camponeses, unidos por interesses comuns, não tinha mais necessidade da lingüística militante e engajada tal como a de Marr, fundada sobre a premissa da luta de classes. A proclamação da natureza destituída de classe, da língua nacional, (que, por definição, era a russa) preparou a concepção da aparição de uma "nova sociedade histórica" denominada "o povo soviético". Confirmada pela Constituição de "Estado de direita socialista", a Língua Russa estabeleceu-se definitivamente como a "língua de comunicação inter-étnica". O postulado da transparência, do caráter estável e apolítico(destituído de classe) da língua nacional coincide com a completude, aperfeiçoamento do discurso estático do regime comunista. Os limites do que é dizível na língua nacional marcam também os limites do pensável: o conteúdo socialista internacional se exprime facilmente na língua "inter-étnica" ao alcance de todo cidadão qualquer que seja sua origem. Esta língua se mostra um meio eficaz da delimitação do pensável pelo dizível. Privada de tensões antagonistas e de "refrações de classe" ela se condensa em estruturas monovalentes perfeitamente orgânicas, em virtude de coincidências absolutas entre conteúdo e forma, devido à instância heterogênea, onde toda alteridade se encontra apagada em seu interior, mas, sobretudo, porque o dizível neste quadro é tornado efetivamente o decalque exato do pensável.

Tudo se passa como se até junho de 1950 Stalin tivesse concluído que a figura de hostilidade, o procedimento da luta ou da clivagem permanente entre a forma e o conteúdo nas relações sociais não tivesse mais utilidade na sociedade soviética. Isso não poderia significar senão uma coisa: a conformidade completa do conteúdo de toda consciência individual às formas lingüísticas pré-existentes e a impossibilidade de pensar qualquer coisa não-exprimível nas formas lingüísticas fixas ofertadas por esta língua purificada. Esta língua $<$ do povo inteiro $>$ assegurando a "comunicação interétnica" se dá como realização e triunfo do ideologema, esta criação conceitual de Volochinov, aliás Bakhtin, compreendida como abolição radical da fronteira entre o social(discursivo) e o psicológico (a consciência).

\section{REFERÊNCIAS BIBLIOGRÁFICAS}


ALPATOV, V. Istorija odnogo mifa.[História de um mito], Moskva, Ed. Nauka, 1991.

Moskva, 1998.

Istorija lingvistitcheskikh utchenij.[História das teorias lingüísticas],

BAKHTINE,Mikhail.(Medvedev, Pavel),[1928] Formalnyij metod v literaturovedenii

. Bakhtine pod maskoj 2. [Bakhtin sob a máscara 2], Moskva, Ed. Labirint, 1993.

Ttraloguija.[Tetralogia] Moskva, Ed. Labirint, 1998.

BALZAC, Honoré de [1842] Avant-propos de la comédie humaine. In: La comédie humaine 1, Etudes des moeurs: scènes de la vie privée. Paris, Ed. Gallimard, 1976.

BENJAMIN, Walter.Charles Baudelaire. Un poète lyrique à l'apogée du capitalisme.Paris, Ed. Payot, 1982.

BUICAN, D. Lyssenko et le lyssenkisme. Paris, 1988.

CLARK, Katerina \& HOLQUIST, Michael. Mikhail Bakhtine, Cambridge/London, Harvard University Press, 1984.

Dictionnaire Le Robert. Dictionnaire historique de la langue française.REY, Alan(org), t.3, Paris, 1975.

GOETHE, Jochann Wolfang Von[1790] La métamorphose des plantes. Paris, Ed. Triades, 1975.

GROIS, Boris. L'utopie et la tromperie. Style Staline.Du nouveau. Articles. Moskva, Znak,1993.

KRISTEVA, Julia. Polylogue. Paris, Ed. Seuil,1977.

LAFARGUE,Paul.

NISBET, Henry. Goethe and the scientific tradition. London, Institue of Germanic studies, Univ. of London, 1972.

PEYTARD, Jean. Mikhail Bakhtin. Paris, Ed. Bertrand-Lacoste,1995.

Les nouvelles maladies de l'âme. Paris,Ed. Fayard,1993.

SCHAEFFER, Jean -Marie. La naissance de la litteratue. La théorie esthétique du romantisme allemand.Paris, Ed. Gallimard,1983.

STALINE, I. Marksism i problemy jazykoznania. [O marxismo e os problemas da lingüística] In: Works,vol. 3, STANFORD, Califórnia, The Hoover Institution on War, Revolution and Peace, 1967.

STEINER, Peter. Russian formalism. A metapoetics. Ithaca, London Cornell University Press, 1984.

THOMAS,Lawrence. The linguistics theories of N. Ja. Marr. Berkeley, 1957. VOLOCHINOV, V. (BAKHTINE, M.) Frejdizm[Freudismo].Leningrad,1927. 